\title{
Global Health Governance on Cruise Tourism: A Lesson Learned From COVID-19
}

\author{
Zhengliang Hu and Wenwen Li* \\ School of Law, Shanghai Maritime University, Pudong, China
}

Cruise tourism is becoming increasingly popular worldwide. However, the health and safety of thousands of cruise tourists have been put in jeopardy due to the COVID19 pandemic. The refusal of cruise ships calling has been the most significant reason behind the health hazards faced by passengers. Moreover, some coastal States have decided to close their borders, leaving passengers to their own fate in the case of a COVID-19 outbreak on board. Situation analysis contributes to demonstrating obstacles encountered in public health governance on cruise tourism. Information is collected from official websites of governments and international organizations to investigate the reasons behind the non-compliance of these countries with the International Health Regulations (IHR) (2005). Academic literatures showcase different views on the necessity

OPEN ACCESS

Edited by:

Elizabeth Mendenhall, University of Rhode Island,

United States

Reviewed by:

Yen-Chiang Chang, Dalian Maritime University, China Liu Xiaofei,

Weifang University, China

*Correspondence: Wenwen L 515931723abc@sina.com

Specialty section: This article was submitted to Marine Affairs and Policy, a section of the journal Frontiers in Marine Science

Received: 19 November 2021 Accepted: 10 January 2022 Published: 03 February 2022

Citation:

Hu Z and Li W (2022) Global Health Governance on Cruise

Tourism: A Lesson Learned From COVID-19. Front. Mar. Sci. 9:818140.

doi: 10.3389/fmars.2022.818140 of revising the IHR (2005). Statistical analysis is used to assess core capacities required by the IHR (2005) of the coastal States. Coastal States reserve their rights to refuse foreign cruise ships to enter ports and to prevent the persons aboard from embarking or disembarking so long as conditions under Article 43 are met. However, some foreign cruise ships were directly refused to call by various coastal States without scientific evidence. This practice stems largely from the high risk of COVID-19 outbreaks in cruise ships and the resulting burden from the cruise pandemic response. Compared with improving IHR (2005), especially its dispute settlement mechanism, helping coastal States to boost their core capacities is more conducive to solving the problem of cruise public health governance. The improvement of core capacities can be carried out from the aspects of surveillance of cruise ships and risk assessment, medical examinations on cruise travelers, cruise design and cruise tourism management.

Keywords: global health, cruise tourism, International Health Regulations, core capacities, COVID-19

\section{INTRODUCTION}

The popularity of cruise travel has increased rapidly in recent years. According to the statistics from the International Cruise Association (CLIA), in 2019, the global cruise industry welcomed nearly 30 million passengers, provided employment to 1.8 million people worldwide, and contributed more than US $\$ 1540$ billion to the global economy. However, in 2020, the 2019 novel coronavirus disease (COVID-19) pandemic and the resulting commercial cruise business suspension entailed a major blow to the cruise industry. Consequently, from mid-March to September of the same year, the cruise industry suspension caused global economic losses of 77 billion US dollars, and job losses of 518000 (CLIA, 2021). 
Nearly 100 countries and regions have closed their maritime borders and banned the arrival of cruise ships during the pandemic (Cruise Critic, 2021). Moreover, some individual cruise ships were refused to call at ports by various coastal States. In February, the Dutch-flagged cruise ship Westerdam with passengers suspected of being infected with COVID-19 virus onboard (hereinafter "suspect passengers" or "suspect persons") was refused to call at Manila in the Philippines, Kaohsiung in Taiwan, China, Ishigaki in Japan, Guam in the United States and Laem Chabang in Thailand (Travel Agent Central, 2020). The Maltese-flagged MSC Meraviglia with suspect passengers was refused to call at Ocho Rios in Jamaica and George Town in Grand Cayman (Puhak, 2020). In the same month, the Italianflagged AIDA Perla with persons who tested positive for COVID19 was refused to call at Saint Lucia and in Dominica (Cruise Industry News, 2020). In March, the Dutch-flagged Zaandam with passengers infected with COVID-19 virus (hereinafter "affected passengers" or "affected persons") onboard was refused to call at Punta Arenas in Chile (Harris, 2020). In the same month, The Australian-flagged Breamar was refused to call at ports in Dominica, Barbados, and Bahamas (Stuff, 2020). Several cruise ships on which persons showed no symptom of COVID-19 were also refused to call at ports, e.g., in March, the Italian-flagged Costa Fortuna at Phuket in Thailand and Penang in Malaysia (Insider, 2020), and the British-flagged Golden Princess at Acaroa in New Zealand (Lewis et al., 2020).

At the same time, some of the coastal States agreed to the entry of cruise ships. For instance, the Italian-flagged Costa Serena was allowed to call at Tianjin in China on 24 January, and the Italian-flagged Costa Venezia was allowed to call at Shenzhen in China on 26 January 2020. All the passengers and crewmembers onboard (collectively as "persons") were allowed to disembark after going through health inspection by China EntryExit Inspection and Quarantine Bureau. However, passengers with flu-like symptoms were only allowed to disembark after a negative COVID-19 test. The passengers having Wuhan in their itineraries were placed in hotel rooms for further observation.

The IHR (2005), effected in June 2007, are legally binding under Articles 21 and 22 of the WHO's Constitution on 196 countries, including all WHO Member States. The IHR (2005) formulated international standards, requiring member states to implement these standards to cope with and prevent the international spread of diseases. As stipulated in the IHR (2005) Article 28 requires, "Subject to Article 43 or as provided in applicable international agreements, a ship shall not be prevented for public health reasons from calling at any point of entry. However, suppose the point of entry is not adequately medically equipped to apply health measures under these Regulations. In that case, the ship may be ordered to proceed at its own risk to the nearest suitable point of entry available to it, unless the ship has an operational problem, making this diversion unsafe." Moreover, "Subject to Article 43 or as provided in applicable international agreements, ships shall not be refused free pratique (defined as permission for a conveyance to enter a port to embark or disembark, to discharge or load cargo or stores) by States Parties for public health reasons; they shall not be prevented from embarking or disembarking, discharging or loading cargo or stores, or taking on fuel, water, food, and supplies. States Parties may subject the granting of free pratique to inspection and, if a source of infection or contamination is found on board, the carrying out of necessary disinfection, or other measures necessary to prevent the spread of the infection or contamination." Meanwhile, WHO often advises against any form of travel restrictions (WHO, 2019, 2020).

Despite the provisions of the IHR (2005) and WHO's advice, some coastal States have still imposed cross-border control measures (Table 1), focusing on travel restrictions during the current outbreak of COVID-19 to prevent disease transmission (Lee et al., 2020). As of 11th April 2020, 167 countries, territories and areas implemented additional health measures that severely impacted international traffic as defined under Article 43 of the IHR (2005), ranging from flight suspensions, visa restrictions, border closures, and quarantine measures (WHO, 2020). A total of 16 global health law researchers concluded that imposing travel restrictions during the current outbreak of COVID-19 breaches IHR (2005) (Habibi et al., 2020). However, only few studies have delved into the legality of ports refusing cruise ship calls under IHR (2005) to our knowledge (Klein, 2020; Tirrell and Mendenhall, 2021). Therefore, we hereby construct Article 28 and Article 43 of IHR (2005), conducting an in-depth analysis of their correlativity on the application. As for dealing with non-compliance to the regulations, we suggest improving core capacities required under the IHR (2005) rather than amending the Regulations.

\section{MATERIALS AND METHODS}

\section{Situation Analysis of Coastal States Refusing Cruise Ship Calls}

This health policy research analyzed COVID-19 responses to foreign cruise ships, especially refusal of entry of cruise ship into ports, in several coastal States and regions. A situation analysis is a widely adopted method in health policy research to comprehend the actual situation of any given context (Sarkar et al., 2020). The adoption of situation analyses demonstrates the popular non-compliance or partial compliance with the IHR (2005) around the coastal States worldwide.

Based upon the coastal States' refusal practices, this study also investigated the reasons behind the countries' non-compliance

\begin{tabular}{|c|c|}
\hline \multirow[t]{5}{*}{ Cruise tourism } & Travel warning \\
\hline & Travel advisory \\
\hline & Suspend transportation \\
\hline & $\begin{array}{l}\text { Restrict entry of selected foreign nationals on the basis of nationality, } \\
\text { travel history, or health status }\end{array}$ \\
\hline & Close national borders \\
\hline \multirow{5}{*}{$\begin{array}{l}\text { Entry and exit } \\
\text { controls at } \\
\text { national borders }\end{array}$} & Compulsory temperature measurement \\
\hline & $\begin{array}{l}\text { Compulsory questionnaire (i.e., symptoms, travel history, contact } \\
\text { tracing) }\end{array}$ \\
\hline & Voluntary quarantine upon entry \\
\hline & Voluntary testing upon entry \\
\hline & Mandatory certification (i.e., vaccination, disease free status) \\
\hline
\end{tabular}


with the IHR (2005), considering the severity of their national pandemics. Information was collected from the No Sail Order lifted by CDC (CDC, 2020a), the Interim Advice lifted by the EU Healthy Gateways Joint Action, and official websites of governments and international organizations, such as WHO, CLIA.

\section{Literature About Dispute Settlement Mechanism of IHR (2005)}

The IHR (2005) exerts a significant influence in providing the core capacity construction of global health governance, which is an important tool in global health governance (Gostin, 2014). This study has also analyzed whether the IHR (2005) needs to be revised, especially its dispute settlement mechanism. Data of different views were mainly sourced from academic databases and historical documents.

\section{Statistical Analysis}

It was confirmed by statistical data continuously collected from January to March 2020 that COVID-19 infectious rates in port States accepting cruise ships were higher than the rates in countries refusing the calling of cruise ships (Ito et al., 2020).

Statistical analysis is also used to assess core capacities required by the IHR (2005). The analysis is conducted on the core capacities at designated international ports' points of entry $(\mathrm{PoE})$, a passage for international entry or exit of travelers, baggage, cargo, containers, conveyances, goods, and postal parcels, as well as agencies and areas providing services to them on entry or exit.

\section{RESULTS}

\section{Global Health Governance on Cruise Tourism}

\section{Cross-Border Transmission of Infectious Diseases and Global Health Governance}

"The age of globalization is the age of universal contagion" (Negri and Hardt, 2000). The records of the Vessel Sanitation Program (VSP) of the Centers for Disease Control and Prevention (CDC) show that cruise public health and safety events are a yearly occurrence (CDC, 2021). Combined with the remarkable globalization characteristics of the international cruise industry, the public health risk of international cruise has become the core problem in the development of the international cruise economy.

Solving international public health problems in different periods requires different governance models and an international health legal system matching the governance models. In the context of globalization, pandemic prevention work can no longer be regarded as the responsibility of a single country.

Taking the IHR (2005) as an example, it shows obvious differences in the governance models of international public health events between the 1969 version of the regulations and the 2005 version of the regulations. The former emphasizes the control of sovereign states over their borders. Countries reserve the rights to prevent the import of viruses by restricting entry-exit personnel means of transport and goods. The latter requires countries to improve the core capacity of public health and to implement measures to deal with public health emergencies.

The historical evolution of the regulations shows that the mode of international public health governance has changed from individual operation to international cooperation. Global health governance must be adopted to address public health emergencies of cruise tourism (Gostin and Mok, 2009). Global public health governance refers to a global governance mechanism and governance model for countries, international organizations, and other diversified subjects to address the issues of international public health security by establishing universally binding international rules. Its core elements are composed of the following aspects: First, using deterritorialization in solving public health problems; second, adopting a crosssectoral perspective to analyze and respond to public health issues, and boost cooperation with trade, economy, diplomacy, environment, agriculture and other departments and fields; third, attracting more participants through formal or informal channels (Liu, 2020).

\section{The Jurisdictional Conflict Between Port States and Flag States}

After cruise ships enter and call at foreign ports, a conflict arises between the territorial jurisdiction of the port States and the flag States. To respond to the cruise tourism pandemic, the question is, which country should bear the management responsibility for the cruise ship, the flag State or the coastal State? This issue involves the theory of jurisdictional conflict in international maritime law.

On the one hand, Article 2 of the United Nations Convention on the Law of the Sea of 1982 (UNCLOS) confirms that the "sovereignty of a coastal State extends, ... to an adjacent belt of sea, described as the territorial sea." Therefore, once a foreign ship enters the territorial sea or internal waters of a coastal State, both the ship and people onboard are subject to the port State's administrative jurisdiction and judicial jurisdiction, provided that she enjoys the right of innocent passage in the territorial sea. On the other hand, paragraph 1 of Article 94 of the (UNCLOS) clearly stipulates that "every State shall effectively exercise its jurisdiction and control in administrative, technical and social matters over ships flying its flag." As the cornerstone of international law, State sovereignty encompasses internal and external sovereignty. The internal sovereignty includes territorial and personal supremacy. That is to say, the territorial supremacy of a State is above all the people and things within its territory.

State Sovereignty extends to inland waters covering waters near the territory over which the State exercises its sovereignty. These waters include those of ports, bays and estuaries (Ortolland and Pirat, 2017). Ports are the actual trading places for ships whereby passengers and goods can embarked and disembarked and which are essentially open to the world and have their access restricted by the States owning them (Choquet and Sam-Lefebvre, 2020).

In fact, there is a relatively clear answer to the aforesaid question. The major significance of flag State jurisdiction in 
modern times should be to solve the problem of jurisdiction when ships and aircrafts are on the high seas or over the high seas, to prevent such means of transport from encountering jurisdictional dilemmas due to their geographical location departing from the territorial sovereignty of their countries, that is, to avoid the loss of jurisdiction. Therefore, the effectiveness of flag State jurisdiction should not be exaggerated (Sun and Jin, 2020). Still, port States are also subject to the norm of nondiscrimination among flag States (Tirrell and Mendenhall, 2021). What's more, from a practical perspective, the requirements or suggestions on the jurisdiction of the shipping country put forward by international organizations and sovereign States during the pandemic are all related to conventional ship management, which focuses more on port (coastal) States. For instance, the International Maritime Organization (IMO) guides port States on extending the validity of certificates (IMO, 2021). It has also become the practice of some countries to put forward guidelines regarding port States surveys and the extension of ship and personnel certificates (Icelandic Transport Authority, 2020; Luxembourg Ministry of Economic, 2020). Therefore, port States take on more responsibility for ship certificate management regarding global governance on cruise tourism.

\section{Global Health Governance on Cruise Tourism in International Law International Regulations on Global Health Governance on Cruise Tourism}

International treaties and international customs are the two main sources of international law that deal with the global health governance on cruise tourism. The former prevails in the public health context (Fidler and WHO, 2002). In modern times, countries have signed numerous treaties to address the threat of widespread disease contamination, from the International Sanitary Convention (ISC) in 1892 to today's IHR (2005). The IHR (2005) aims to strengthen global health security by imposing obligations and rights to Member States and promoting the international community to prevent and respond to serious public health risks that could potentially cross borders and threaten people worldwide.

The IHR (2005) has been established under the authority of Articles 21 and 22 of the WHO constitution, effectively allowing the WHO to devise regulations on "sanitary and quarantine requirements and other procedures designed to prevent the international spread of disease." Therefore, the IHR (2005) is a binding legal instrument for all WHO Member States and its legally binding force has become a consensus in global health governance (Gostin et al., 2015). However, the WHO is generally constrained by the limited legislative and enforcement power of Member States, so provisions of the International Health Regulations are inclined to provide guidance without sanctions (Liu and Chang, 2020). Therefore, the WHO prefers to issue recommendations pursuant to Article 15 and Article 16 of the IHR (2005) for application on a time-limited, risk-specific basis in response to public health emergencies of international concern (hereinafter "PHEIC"). These recommendations issued by WHO are non-binding pieces of advice.

\section{International Customary Law on Port Access Permission Right}

The power of port States to exercise port access is also limited by international customary law. During the pandemic, to prevent and control the import of the virus through foreign ships attached to their ports, many countries have prohibited or strictly restricted the calling of foreign ships by exercising the port access permission right, reflecting the exercise of national sovereignty by coastal States. For example, the Malaysian Government announced a national lockdown on 18 March 2020, and Australia banned cruise ships arriving from foreign ports from 15 March 2020 (Conventuslaw, 2020). Article 9.1 of the COVID-19 Public Health Response (Maritime Border) Order (No 2) 2020, promulgated on September 6, 2020 in New Zealand, stipulates that "Foreign ships are not permitted to arrive in New Zealand." Article 9.2 stipulates that "Despite subclause (1), a foreign ship is permitted to exercise, in accordance with the United Nations Convention on the Law of the Sea, the right of: (a) innocent passage through territorial seas; or (b) transit passage through straits used for international navigation." Similarly, the U.S. government played an early response to the epidemic in January, has adopted strict border control measures and issued the highest-level travel warning (Global Biodefense, 2020). Moreover, the British government has implemented measures to prevent the import of cases by March, including strengthening border detection and formulating COVID-19 health protection regulations (U.K. GOV, 2020).

However, limits have been imposed to coastal States to exercise the port access permission right. For humanitarian and security reasons, customary international law holds that ships in distress enjoy the right to enter any foreign port (Yoshifumi, 2015). In other words, the coastal State should allow ships of foreign nationality in distress to enter its ports to defuse a dangerous situation. Crew members or passengers infected with the virus onboard may cause the ship to be in a state of distress (Morrison, 2012). When it comes to cruise ships, contamination amongst the crew surpassing the minimum crew requirement would endanger the safety of the ship and thereby create a situation of distress (Klein, 2020). During the pandemic, crew memebers' contracting the virus that prevents them from effectively performing their duties puts their lives, health and safety at risk, and they need prompt medical attention. Other seamen on the same ship need to be quarantined, thus causing the normal service level of the ship to be affected and impacting the ship's seaworthiness. Thus, the coastal State shall allow the foreign cruise ship to call at the port in the case of COVID-19 outbreak onboard and entering a state of distress.

\section{"Soft Law" Approach on Global Health Governance on Cruise Tourism}

In the public health governance mechanism, "soft law," namely non-binding norms, is more likely to be applied for the reason that it provides a way to harmonize international public health policies (Fidler and WHO, 2002). As a specialized agency of the United Nations, the IMO is responsible for formulating global standards for international shipping safety and environmental 
protection, and creating a fair, effective, universally adopted and implemented a regulatory framework for the shipping industry. During the COVID-19 outbreaks, the IMO issued nonmandatory guidance in the form of circulars and proposals to direct pandemic prevention and control on board.

On January 31, 2020, IMO issued circular letter 4,203 and circular letter 4,204. The former aimed to provide information and guidance on the prevention and control of infection for delegates attending the IMO conference. The latter provides information and guidance for crew members, passengers and other ship personnel to take precautionary measures to mitigate the risk of infections. On February 19, 2020, the IMO issued Circular Letter No. 4,204-add. 1 and recommended that the Member States ensure that passengers can embark and normally disembark under appropriate conditions. Relevant authorities can issue certificates to avoid unnecessary restrictions and delays on crew change. On February 21, 2020, the IMO issued Circular Letter No. 4,204/add. 2 with the theme of "IMO-WHO joint statement on coping with covid-19 pandemic" to assist countries in ensuring that health measures are implemented to minimize unnecessary interference with international traffic and trade. On April 14, 2020, IMO issued Circular Letter No. 4204/add 8 , where a joint statement of the global PSC mechanism on responding to the pandemic situation was issued in the annex to promote coordinated action, assistance and practical practices of PSC inspection during the COVID-19 pandemic. On April 22, 2020, the IMO issued Circular Letter No. 4204/add 10, a publication with the theme of "A Joint Statement on Medical Certificates of Seafarers, Ship Hygiene Certificates and Medical Care of Seafarers in the Context of the COVID-19 Pandemics" and appealed to governments of all countries to ensure the health and medical care of crew members, to carefully implement control measures, to properly facilitate ship transportation and to effectively communicate information. On May 5, 2020, IMO issued Circular Letter No. 4,204/add 14, followed by a framework of recommended agreements on crew shifts and safe travel during the pandemic. On July 1, 2020, the IMO issued a proposal entitled "Coronavirus (COVID-19)-Recommendations for port and coastal States on the prompt disembarkation" to meet the needs of global crew members for medical services during COVID-19 outbreaks on board. However, these circulars on shipping and crew medical care can only provide suggestions to the Member States, which for sure reflect the international concentration on the issue. While all the "soft laws" above are not legally binding, and attention should be paid more to construction and application of international treaties, conventions, or regulations such as IHR (2005).

\section{Construction of Article 28 and Article 43 of IHR (2005)}

As mentioned before, cruise ships have been refused to call during the outbreak and spread of COVID-19. Whether a coastal State should grant free pratique to a foreign cruise ship with COVID-19 or other pandemic risks, especially where there are affected or suspect persons onboard, proves to be the most prominent legal issue.

On the one hand, Article 28 of the IHR (2005) provides the general obligation of a coastal State to grant free pratique. In the case of a foreign cruise ship having patients suffering from COVID-19 or other transmissible diseases, granting free pratique to her is a precondition of, and even conducive for the coastal State to promptly and effectively provide medical assistance to the affected or suspected persons and to play an important role in protecting the health and safety of all the persons onboard.

Thus, by virtue of Article 28 (1) and (2) of IHR, in principle, a coastal State shall not refuse free pratique to a foreign cruise ship for public health reasons to enable her to enter a port and to enable the persons on board to embark or disembark, whether there are affected or suspect persons on board or not and regardless of their numbers.

On the other hand, Article 43 of the Regulations makes proviso of the general obligation of free pratique. Article 28.1 and 28.2 of IHR (2005) stipulates that the obligation of a coastal State to grant free pratique is subject to Article 43 thereof. Article 43 allows the State parties to implement additional health measures as per their relevant national law and obligations under international law in response to specific public health risks or PHEIC, but subject to several conditions (Table 2).

In the event of a foreign cruise ship pandemic, it will be very difficult to meet the conditions mentioned above in practice. To be specific, refusal of free pratique will or may cause prejudice in the implementation of prompt health measures by related States and thus will not "achieve the more appropriate level of health protection" than the case of the port state's granting free pratique, unless the coastal State possesses extremely deficient sanitary situations. Moreover, the condition of "such measures are otherwise consistent with these Regulations" contained in Article 43.1.b seems ambiguous. As a result, it will be very difficult or even impossible to justify the refusal of free pratique to a foreign cruise ship with COVID-19 or other pandemic risks by availing of the provisions of Article 43 of IHR (2005).

\section{Defects in Decision-Making}

Under Article 43.2 of the IHR (2005), Member States cannot implement additional health measures exclusively as a precaution but must rather ground their decision making in "scientific principles" and "scientific evidence." They shall conduct a risk

TABLE 2 | Conditions of implementing additional health measures.

\begin{tabular}{|c|c|}
\hline Article & Conditions \\
\hline \multirow[t]{3}{*}{$43(1)$} & $\begin{array}{l}\text { a. Achieving the same or greater level of health protection than } \mathrm{WHO} \\
\text { recommendations; }\end{array}$ \\
\hline & b. Consistent with these Regulations; \\
\hline & $\begin{array}{l}\text { c. Not being more restrictive of international traffic and not more invasive } \\
\text { or intrusive to persons than other reasonably available alternatives. }\end{array}$ \\
\hline \multirow[t]{3}{*}{$43(2)$} & a. Scientific principles; \\
\hline & b. Available scientific evidence and information; \\
\hline & c. Available specific guidance or advice from WHO; \\
\hline $43(3)$ & $\begin{array}{l}\text { Providing to } \mathrm{WHO} \text { the public health rationale and relevant scientific } \\
\text { information. }\end{array}$ \\
\hline $43(4)$ & Reconsidering the application of the measures if requested by $\mathrm{WHO}$. \\
\hline $43(5)$ & Informing WHO within 48 h of implementation. \\
\hline 43(6) & Reviewing such a measure within 3 months. \\
\hline $43(7)$ & Consulting with any State Party impacted by such a measure. \\
\hline
\end{tabular}


assessment on the facts and take the assessment results as the basis of policy formulation before taking further measures. Such an assessment is called "evidence-based risk assessment" (EBRA) and the resulting policy is called "evidence-based policy" (EBP). EBP highlights the use of evidence tested by scientific procedures and empirical methods as the basis for policymaking. Thus, where a foreign cruise ship applies for calling and free pratique, risk assessment of the port States should be implemented to gauge whether it possesses ample response capacities and pick the appropriate sanitary measures. The risk assessment shall be made scientifically by using available evidence of risks to the public health onboard and potentially to the public health of the port State. It seems helpful or necessary for a coastal State to conduct EBRA before taking health measures to ensure the measures be taken scientifically and adhering to the requirement of granting free pratique provided for in Article 28.1 and 28.2 of IHR (2005). Thus, where a foreign cruise ship applies for free pratique, risk assessment is necessary for a coastal State to judge whether it can respond and what health measures are to be implemented. The risk assessment shall be made scientifically by use of available evidence of risks to the public health of cruise ships.

Noticeably, some foreign cruise ships' application for free pratique were directly refused by various coastal States neglecting EBRA during the pandemic. As mentioned in the Background, after leaving from Hong Kong on 1 February 2020, the cruise ship Westerdam with 1,455 passengers and 802 crew members had been refused free pratique by five states before she was finally allowed to enter Sihanouk in Cambodia on 13 February, although no affected or suspect person was identified. Another example is that, after leaving from Miami on 23 February 2020, the cruise ship MSC Meraviglia with 4,580 passengers and 1,600 crewmembers onboard had been refused to enter by two States before she was finally allowed to enter Cozumel in Mexico on 28 February. However, the medical records showed only one case of seasonal influenza onboard, and the patient had never been to any COVID-19 afflicted areas.

However, under Article 27 of the IHR (2005), coastal States shall take measures to control the point of entry, or, if coastal States are not able to carry out the required measures, the competent authority shall, nevertheless allow the departure of the aircraft, ship or ground transport, subject to informing the competent authority at the next known point of entry of the evidence found and the control measures required.

\section{Reasons for Coastal States' Refusal High Risk of COVID-19 Outbreaks in Cruise Ships}

Respiratory infections, GI infections and other vaccinepreventable diseases are mostly involved in cruise ship disease outbreaks (Tardivel et al., 2016). In 2020, COVID-19 outbreaks occurred in about 40 cruise ships worldwide (Table 3; Wang, 2020). The followings are accountable for this:

First, the public nature of cruise facilities leads to frequent direct or indirect contact among passengers. Cruise tourism usually involves the movement of people in closed or semi-closed environments. Passengers share sanitary and air-conditioning systems on board, with public areas such as restaurants and recreation rooms, spas and swimming pools. In these public areas, door handles, faucets, elevator buttons, handrails of stairs and passages and appliances in the buffet are common contact surfaces among passengers. These contact surfaces became the medium of virus transmission among passengers.

Second, the characteristics of passengers on the cruise ships are conducive to the spread of infectious diseases. As to the scale, the cruise industry responds to the increasing number of passengers by increasing the scale and capacity of cruise ships. Some large cruise ships carry over 5,000 passengers at a time. As to the sources, passengers on board often hail from different countries and bear different immune and health conditions. As to the age pattern, the typical cruise passengers are usually the elderly category. Industry trade publications show that $51 \%$ of cruise passengers are over 50 years old. For example, the median age of the passengers on the "Grand Princess" cruise ship was 66 years old, and the 1,200 passengers on board were over 70 years old (EU Healthy Gateways, 2020). Some elderly people may suffer from chronic conditions which are conducive to the exacerbation of complications. Statistics show that the elderly account for a large proportion of COVID-19 cases with serious infection, hospitalization, complications and death (Smorenberg et al., 2021). The COVID-19 spread on board a British-flagged ship, Diamond Princess, departed from Yokohama on January 20,2020 . The median proportion of passengers over the age of 60 infected with the virus was 19.5, while the median proportion of passengers under the age of 60 infected with the virus was 7.6 (NIID, 2020). The incidence and mortality rates surge with the infection of passengers onboard.

Third, the operation mode of cruise ships is conducive to the spread of viruses among different cruise ships. Crew members infected with the virus may continue working, living on board, and serving many different ships. Once a crew member is infected with the virus, it will be highly probable to spread to other ships.

Fourth, there are defects in the cruise health mechanism. Messaging plays an important role in cruise pandemic prevention and control, meaning that cruise liners are supposed to maintain an open and communicative attitude toward passengers (LiuLastres et al., 2019). However, it is difficult for passengers to recognize the actual risk of infectious disease transmission, and the information dissemination on the cruise ship is not so smooth. For example, On January 19, 2020, the Bahama-flagged World Dream, with 4,482 passengers and 1,814 crew members on board, departed from Guangzhou, China. After the cruise ship returned to Guangzhou on January 24th, 5 passengers and 1 crew member were diagnosed with COVID-19. After the departure of the cruise, passengers who purchased Wi-Fi services learned the news of COVID-19. In contrast, other passengers who could not use the Internet were not aware of the pandemic (Beijing Youth Daily, 2020).

\section{The Relationship Between Cruise Tourism and COVID-19 Infectious Rates in Port States}

On March 8, 2020, the Bermuda-flagged Ruby Princess, carrying around 2,700 passengers and 1,100 crew, departed Sydney and traveled to Fiordland (11 March), Dunedin (12 March), Akaroa (13 March), Wellington (14 March), and Napier (15 
TABLE 3 | Cruise ships with pandemic worldwide.

\begin{tabular}{|c|c|c|c|c|c|}
\hline No. & Name & Occurrence country and region & Region & Number of infected persons & Cruise line \\
\hline 1 & Diamond Princess & Japan & Asia & 721 & Princess Cruise line \\
\hline 2 & Ocean Atlantic & Japan & Asia & 149 & $\begin{array}{l}\text { CSSC-Carnival } \\
\text { Cruise Shipping }\end{array}$ \\
\hline 3 & World Dream & China & Asia & 8 & Dream Cruise Line \\
\hline 4 & Ruby Princess & Australia & Oceania & 663 & Princess Cruise line \\
\hline 5 & Artania & Australia & Oceania & 27 & Phoenix Reisen \\
\hline 6 & Marine Voyager & Australia & Oceania & 26 & Royal Caribbean International \\
\hline 7 & Ovation of the Seas & Australia & Oceania & 13 & Royal Caribbean International \\
\hline 8 & Golden Princess & New Zealand & Oceania & 2 & Princess Cruise line \\
\hline 9 & Ocean Oasis & United States & North America & 157 & Royal Caribbean International \\
\hline 10 & Grand Princess & United States & North America & 78 & Princess Cruise line \\
\hline 12 & Disney Wonder & United States & North America & 38 & Disney Cruise Line \\
\hline 13 & Symphony of the Seas & United States & North America & 31 & Royal Caribbean International \\
\hline 14 & Freedom of the Seas & United States & North America & 14 & Carnival Cruise Lines \\
\hline 15 & Coral Princess & United States & North America & 12 & Princess Cruise line \\
\hline 16 & Zaandam & Panama & North America & 9 & Holland America Line \\
\hline 17 & Braemar & United States & North America & 5 & Norwegian Cruise Line \\
\hline 18 & Majesty & United States & North America & 2 & Royal Caribbean International \\
\hline 19 & Summit & United States & North America & 217 & Celebrity Cruises \\
\hline 20 & Jewel of the Seas & United States & North America & 2 & Royal Caribbean International \\
\hline 21 & Sun Princess & United States & North America & 1 & Princess Cruise line \\
\hline 22 & Carnival Valor & United States & North America & 1 & Carnival Cruise Lines \\
\hline 23 & Celebrity Infinity & United States & North America & 1 & Celebrity Cruises \\
\hline 24 & Explorer of the Seas & United States & North America & 1 & Royal Caribbean International \\
\hline 25 & Norwegian Bliss & United States & North America & 1 & Norwegian Cruise Line \\
\hline 26 & Norwegian Breakaway & United States & North America & 1 & Norwegian Cruise Line \\
\hline 27 & Norwegian Encore & United States & North America & 1 & Norwegian Cruise Line \\
\hline 28 & Greg Mortimer & Uruguay & South America & 130 & Expedition \\
\hline 29 & Eclipse & Argentina & South America & 76 & Celebrity Cruises \\
\hline 30 & Silver Explorer & Chile & South America & 6 & Silversea \\
\hline 31 & Silver Shadow & Brazil & South America & 1 & Silversea \\
\hline 32 & Costa Luminosa & Italy & Europe & 36 & Costa Crociere \\
\hline 33 & Costa Favolosa & Italy & Europe & 6 & Costa Crociere \\
\hline 34 & Ms Braemar & The U.K. & Europe & 5 & $\begin{array}{l}\text { Fred Olsen } \\
\text { Cruise Lines }\end{array}$ \\
\hline 35 & Costa Magica & Italy & Europe & 2 & Costa Crociere \\
\hline 36 & Msc Opera & Greece & Europe & 2 & MSC Cruise Line \\
\hline 37 & Costa Victoria & Italy & Europe & 1 & Costa Crociere \\
\hline 38 & Msc Fantasia & Portugal & Europe & 1 & MSC Cruise Line \\
\hline
\end{tabular}

March) (New Zealand Ministry of Health, 2020). However, some passengers on board were unwell during the journey, showing respiratory disease symptoms. The cruise was shortened, and the ship returned directly to Sydney and passengers disembarked on March 18. 2,700 passengers were allowed to disembark without virus detection. When the health department found that some passengers and crew members were infected with COVID-19, many of them had returned to their homes scattered all over Australia by public transport such as planes and subways. On March 30, at least 440 passengers of the Ruby Princess tested positive and five died. As of April 4, the number of confirmed cases in Australia reached 5,550. It was reported that about $10 \%$ of the confirmed cases in Australia were related to the Ruby Princess (Guardian, 2020b).

The Ruby Princess has certainly not been the only cruise ship posing a threat to the public health of the port States.
At the beginning of the outbreak, the Director general of WHO declared that more than half of the coronavirus cases outside China occurred on the Diamond Princess cruise ship in Japan (Guardian, 2020a). The response of the Diamond Princess has brought great pressure on the pandemic prevention and control work of the Japanese government.

The cases of Ruby Princess and Diamond Princess illustrate that cruise tourism significantly increases the risk and impact of COVID-19 outbreak in coastal States. The disembarkation of passengers at successive ports may lead to the spread of diseases in these ports and can lead to the spread of the disease in communities (CDC, 2020b). Port health authorities face hitherto unknown challenges in handling COVID-19 cases since there are many uncertainties about the emerging of new cases and the effect of specific measures is unclear. Therefore, cruise ships 
may pose a serious cross-border threat to the health of the transportation sector.

\section{The Great Burden of Cruise Pandemic Response}

During the COVID-19 pandemic, the removal of travel restrictions will greatly burden policymakers in terms of medical resources and costs. First, with the spread of the pandemic, public health authorities are overburdened with community measures and may cause abundant resources to stream to the passengers' evacuation from large cruise ships. The intensive care requirements for cruise passengers with serious diseases have already stretched the health care system and caused a shortage of beds for patients and other health care conditions. For instance, more than 3,700 persons on the British-flagged cruise ship Diamond Princess had been placed onboard for quarantine inspection for 2 weeks before they were allowed to disembark at Yokohama in Japan in February. One of the reasons was that the symptomatic patients have been transported to the designated medical institutes, resulting in all the beds in Kanagawa Prefecture were soon filled (Yamahata and Shibata, 2020). Response to COVID-19 outbreaks on cruise ships diverts medical resources from people with other medical problems and other COVID-19 cases. The continuous attention to curb and slow down the spread of COVID-19 on cruise ships has consumed a considerable diagnostic, treatment and protective equipment and drawn a great deal of resources from coastal States. Due to the increasing number of reported cases and the current pressure on its medical system, authorities would find it challenging to respond to possible outbreaks on cruise ships.

Second, safe evacuation, diversion, isolation and repatriation of cruise ship passengers generate financial costs on governments at all levels, and transfer resources to increase efforts to inhibit or reduce the spread of virus. Most of the coastal States lack experience in addressing cruise pandemic responses and there are still many uncertainties about the recovery of their costs arising out of the aforesaid proceedings (EU Healthy Gateways, 2021). A costs analysis of response to cruise ship pandemic should be conducted. We hereby provide a table about indicators of cost analysis in public security emergencies by virtue of relevant regulations and documents to facilitate the following analysis (Table 4).

\section{DISCUSSION}

\section{Global Governance Mechanisms on Cruise Tourism in International Law Dispute Settlement Mechanism of the IHR (2005)}

Article 56 of the IHR (2005) governs the settlement of disputes that potentially arise from the implementation of the provisions under the Regulations. When it comes to cruise tourism, there are two types of disputes. One is the disputes between State Parties due to side effects of travel restrictions taken by coastal States, another is between State parties and the WHO. Apparently, IHR (2005) dispute settlement mechanism excludes affected private individuals, such as travelers and crew members.
Some academic research on the IHR (2005) concluded that the Regulations lack an adequate dispute settlement mechanism. Dispute mediation for economic losses incurred by the use of additional measures including travel and trade restrictions is necessary for strengthening the binding force of IHR (2005) (Gostin et al., 2015). However, none of the procedures provided for by Article 56 of the IHR (2005) has been formally invoked so far due to two reasons: first, the IHR (2005) dispute settlement mechanism can only be started with the consent of both parties, which is highly dependent on the willingness of State Parties to submit their disputes to compulsory adjudication. Negotiation, conciliation and mediation with the Director-General are rigidly voluntary, resulting in few incentives for member States to resolve their disputes in this way (Hoffman, 2014). Second, there is no ensuing concrete legal consequences (Lin, 2020). Therefore, opinions are found that the IHR (2005) itself is a set of technical norms oriented to international cooperation instead of investigating the responsibility (Gong, 2020). Based on the above situation, it is recommended by the IHR-Ebola Review Committee that rather than amending the dispute settlement mechanism of the IHR (2005), a Global Strategic Plan to improve public health preparedness and response should be developed, especially regarding the monitoring of the core capacities required under the Regulations (Burci and Quirin, 2018).

\section{Strengthening Core Capacities for Cruise Ship Pandemic}

\section{Core Capacities Required by the IHR (2005)}

One of the most important goals and tasks of the IHR (2005) is to help State Parties to build core capacities. In the past, one of the problems of IHR (2005) in response to PHEIC relating to core capacity (WHO, 2005). The problems of insufficient core capacity remain during COVID-19 outbreaks. Article 5 of the IHR (2005) provides that "each State Party shall develop, strengthen and maintain ... the capacity to detect, assess, notify and report events in accordance with these Regulations, as specified in Annex 1." Moreover, as required by Article 13 (1) of the IHR (2005), all State parties shall develop, strengthen and maintain their capacity to respond promptly and effectively to public health risks and emergencies of international concern (PHEIC) as set out in Annex 1 .

Annex 1 to the IHR (2005) is subdivided into sections A and B. Section A is devoted to "core capacity requirements for surveillance and response," while section B to "core capacity requirements for designated airports, ports and ground crossings," namely, PoE. Given that their main role in the whole system was established by the IHR (2005), each State party shall make such core capacities available (Table 5) within 5 years from the promulgation of the IHR (2005), that is, by 15 June 2012.

According to the above requirements, coastal States shall make cruise ship pandemic response plans in advance. In addition, Figure 1 shows the core capacities at PoE in some typical coastal States.

It can be seen from the figure that some coastal States get high scores but still fail to respond to cruise pandemics. Plans for PoE should be developed with a focus on risk assessment, 
TABLE 4 | Cost analysis of emergency public security incidents.

\begin{tabular}{|c|c|c|}
\hline Primary indicator & Secondary indicator & Indicator interpretation \\
\hline \multirow{6}{*}{$\begin{array}{l}\text { Prevention and emergency } \\
\text { preparedness costs }\end{array}$} & Institutional and organizational input & Establishment of crisis management organization system \\
\hline & Input of emergency team & Staff engaged in crisis prevention \\
\hline & Asset input & The value of infrastructure built and resources consumed for crisis prevention \\
\hline & Input of research and development & Research on theoretical and technical issues related to public health events \\
\hline & Input of public investment & The cost of public prevention \\
\hline & Input of emergency material reserve & $\begin{array}{l}\text { Supervision, production, reserve, allocation and emergency distribution of } \\
\text { emergency materials }\end{array}$ \\
\hline \multirow{5}{*}{$\begin{array}{l}\text { Monitoring and early warning } \\
\text { costs }\end{array}$} & Input of information system construction & The establishment of basic information database. \\
\hline & Input of testing institution & The establishment of monitoring points, purchase of monitoring equipment. \\
\hline & Input of crisis notification & Analysis and evaluation of information \\
\hline & Identification and adjustment of alert level & Classification, identification and adjustment of early alert level \\
\hline & Input of early warning measures & The closure and restriction of public places. \\
\hline \multirow{4}{*}{$\begin{array}{l}\text { The direct cost of damage } \\
\text { caused by the crisis }\end{array}$} & People loss & Death or disability during crisis \\
\hline & Economic loss & Direct economic loss \\
\hline & Public psychological impact & The extent of the impact on public psychology \\
\hline & environmental harm & Long-term deterioration of the ecological environment \\
\hline \multirow{3}{*}{$\begin{array}{l}\text { The cost of emergency } \\
\text { response and rescue }\end{array}$} & Input of emergency measures & Hazard control, places blocking, mandatory quarantine etc. \\
\hline & Input of rescue measures & $\begin{array}{l}\text { To organize rescue and treatment of victims, provide medical care, } \\
\text { transportation and other public services }\end{array}$ \\
\hline & Input of social self-rescue & Self-rescue from social organizations \\
\hline \multirow{5}{*}{$\begin{array}{l}\text { Cost of recovery and } \\
\text { reconstruction }\end{array}$} & Input of evaluation of the loss & Statistical analysis of personnel and material damage \\
\hline & Input of member's recovery & Human treatment \\
\hline & Input of economic recovery & Communications, transportations etc. \\
\hline & Input of Restoration of social order & Social security maintenance \\
\hline & Input of psychological recovery & Psychological interference measures \\
\hline \multirow[t]{3}{*}{$\begin{array}{l}\text { Cost of international } \\
\text { cooperation }\end{array}$} & Advance input & $\begin{array}{l}\text { Establishment of information communication platform; monitoring the } \\
\text { establishment of mutual assistance systems }\end{array}$ \\
\hline & Medium-term input & International and regional assistance, such as manpower, materials and funds \\
\hline & Late input & Summary and exchange of experience \\
\hline
\end{tabular}

management, and communication (WHO, 2010). When it comes to cruise ship tourism, core capacities at PoE should be strengthened in terms of surveillance, response, notification and verification.

\section{Surveillance of Cruise Ships and Risk Assessment}

Surveillance of cruise ships is the precondition for ensuring a coastal State to take prompt and effective response measures. Surveillance begins with the health or pandemic declaration of a cruise ship. Generally, the ship's agent in the port of call firstly obtains the health information from the medical personnel onboard the cruise ship then reports to the public health authority of the port State. Shipping practice proved that the proceeding is difficult to ensure the integrity and accuracy of information due to the limitation of medical personnel's capability. For example, on 2 July 2016, the Italian-flagged cruise ship Medi Cagliari applied for entry into Qingdao in China, whilst one of the crewmembers was infected with malaria. However, the ship's agency did not obtain the malaria information and failed to report it truthfully in the maritime health declaration. Consequently, the risk assessment made by China's Qingdao Entry-Exit Inspection and Quarantine Bureau was insufficient, resulting in the risk of pandemic spread (Yu et al., 2017). Advisably, it is more effective for the public health authority of the coastal State to contact the medical personnel onboard the ship directly and, when necessary, to dispatch personnel onboard the ship for quarantine inspection.

Moreover, before granting free pratique, a coastal State shall conduct a risk assessment of the ships and take the assessment results as the basis of policy formulation. EBRA is a relatively advanced public policy theory recently formulated in western countries (Zhang, 2017). The United Kingdom is an important advocate of evidence-based policy (U.K. GOV, 1999). In September 1999, the Cabinet Office of the British government published the Professional Policy Making for the Twenty-First Century. The document proposes eight core competencies for professional policymaking, the fourth of which is the capability of "using evidence," that is, to use the best evidence "from a wide range of sources and involves key stakeholders at an early stage" (U.K. GOV, 1999). Therefore, the risk assessment, including the factors to be considered and the procedures to be followed, should be specific in national law or international treaties.

\section{Implementing Medical Examinations on Cruise Travelers}

After obtaining sufficient and accurate information of a cruise ship's public health situation, the competent authority 
TABLE 5 | Core capacities measure of compliance for responding to events that may constitute PHEIC Emergencies (WHO, 2009).

\begin{tabular}{ll}
\hline (a) To provide appropriate public health & 1. Public health emergency contingency plan \\
emergency response & 2. Integration with other response plans \\
& $\begin{array}{l}\text { 3. Training and/or drill exercises } \\
\text { (b) To provide assessment of and care }\end{array}$ \\
for affected travelers & $\begin{array}{l}\text { 2. Affected travelers on board } \\
\text { travelers }\end{array}$
\end{tabular}

(c) To provide appropriate space

(d) To provide assessment and quarantine
1. Space to interview suspect or affected travelers

2. Regularly updated, documented, tested on-site control measures

3 PPE for interviewing ill travelers
1. Assessment of suspect travelers
1.1. Staff
1.2. Procedures for reporting
2.1. Designation of facilities
2.2. Staff
2. Quarantine of suspect travelers

(e) To apply recommended measures

1. Location to apply recommended measures

2. Standard operating procedures

3. Trained Staff

4. Personal protective equipment

(f) To apply entry or exit controls for arriving and departing travelers (g) To provide access to specially designated equipment, and to trained personnel with appropriate personal protection, for the transfer of travelers who may carry infection or contamination

\begin{abstract}
1. Provide access to special equipment
2. Personnel to transport suspect travelers
\end{abstract} 2.1. Appropriate number of trained personnel available to transport
suspected travelers.
2.2. Personnel trained in application of personal protective
equipment and disinfectant techniques.
2.3. Personnel trained in the use of key information regarding
hospital/clinic/diagnostic facilities related to the PoE.

PPE, personal protective equipment; PoE, port of entry.

\section{Core capacities at PoE}

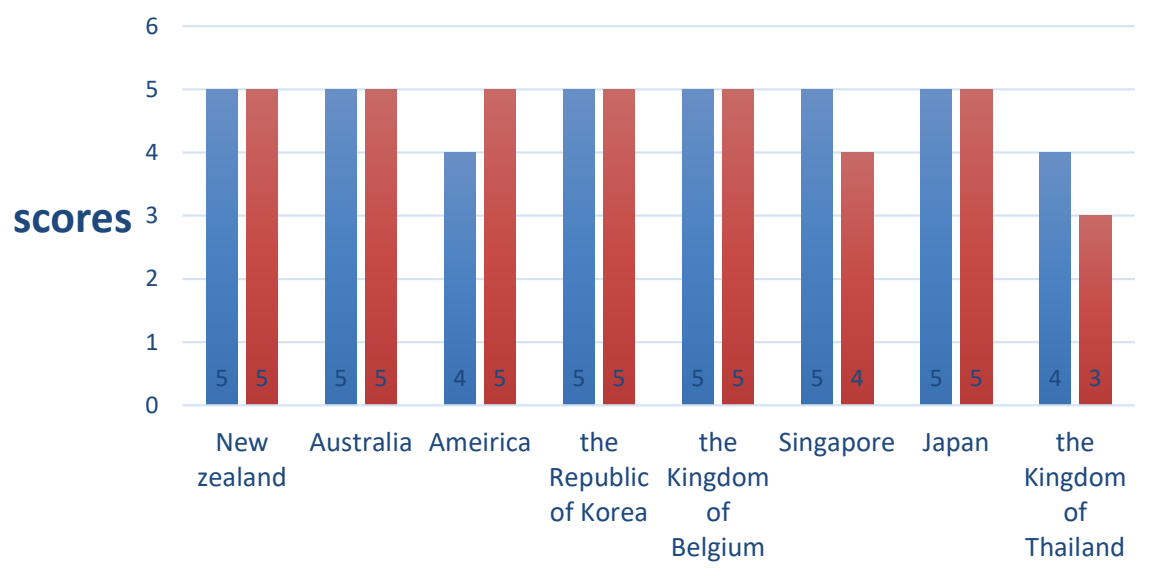

- Routine capacities established at points of entry

Effective public health response at points of entry

FIGURE 1 | Core capacities at the international ports.

shall determine the appropriate medical investigations to be carried out, as required by the principle of reasonable administration. Inspection efficiency and public health information's accuracy and sufficiency shall be considered to enable the coastal State to implement appropriate response promptly and effectively. During the outbreak of H1N1, the cruise ship Diamond Princess called at Qingdao in China in October 2009 and Fuji Maru called at Tianjin in China in January 2010. Quarantine inspection was promptly implemented onboard at anchorage. Consequently, the 
suspected passengers were promptly separated from others (Wang et al., 2010).

\section{Improvements in Cruise Design and Cruise Tourism Management Improvements in Cruise Design}

International cruise ships are huge, with a certain length and height of the hull, which can accommodate a large number of passengers and crew. The huge number of passengers and the relatively narrow space of the ship result in the large personnel density. With the trend of large-scale cruise ships, the risk of disease transmission on board may spike. It is arguable whether it is appropriate for a port State to place and quarantine the suspect persons onboard the cruise ships for public health observation during the outbreak and spread of COVID-19. On 18 February 2020, Kentaro Iwata, a professor at Kobe University Hospital of Japan, highlighted the serious defects in the prevention and control of infectious disease onboard Diamond Princess including the lack of division of safe and dangerous areas, and the lack of professionals responsible for infection control.

Noticeably, a cruise ship has limited and confined space and many passenger cabins are even without openable windows. Most of the current air conditioning and ventilation systems equipped with air purification devices cannot prevent virus transmission onboard. Therefore, cruise ship design plays an important role in limiting the number of people on board and can be used to help reduce the spread of diseases. To achieve this goal, fewer and larger cabins should be created and more independent dining spaces and fewer seats should be created to increase personal space (Brewster et al., 2020).

\section{Improvements in Cruise Tourism Management}

Cruise tourism management is another aspect can be improved to control and reduce the spread of infectious diseases. First, emergency management plans should be made. Cruise lines shall formulate emergency management plans for cruise ships' public health emergencies and strengthen cruise ships' health supervision and disease prevention management. The CDC's VSP program is a good example of an emergency management plan but is limited to GI illnesses on cruise ships (CDC, 2018). A detailed and operable emergency disposal process to address potential public health emergencies on the cruise line is necessary for cruise tourism management. The emergency management plan shall include the following: first, how to quickly isolate the infected passengers and crew after the occurrence of infectious diseases; second, how to quickly respond and utilize onboard doctors; third, how to sterilize the internal space of the cabin; fourth, how to offer comfort and psychological counseling for the crew and passengers.

Second, new operation models and digital creativity should be adopted. The pandemic will not only promote the development of new business forms and new operation models, but also make them more mature. Furthermore, the social communication environment brought about by the pandemic will also promote the innovation and application of digital and intelligent technology. The cruise industry direly needs more new operation models and digital creativity, including the production intelligence of shipyards, public health services and online ticket purchase, which will promote the digitalization of the cruise industry and promote the upgrading of the industry to informatization and intelligence.

Third, professional training should be organized for stuff on board. Each cruise line shall require relevant personnel to receive professional training on the identification of infectious disease symptoms, isolation care, close contacts epidemiological investigation, transfer of suspected infected personnel, and psychological counseling, etc.

Forth, communication and coordinated response with port supervision departments should be strengthened. Infectious diseases outbreaks in large cruise ships may lead to a surge in the number of infected people onboard in the short term. The treatment of confirmed cases and response to serious outbreaks rely on the port State government and massive port transfer and treatment facilities are required (Liu and Chang, 2020). All countries have established relevant organizations or institutes such as maritime emergency rescue and ship navigation safety supervision. When entering or leaving a specific sea area, each cruise ship company will strengthen communication and contact with the port supervision units in time, to get appropriate rescue and guidance during public health emergencies.

\section{CONCLUSION}

Cruise tourism has developed rapidly in recent years, and there has not been such a large-scale refusal of cruise ship calls due to PHEIC. While this study focuses on the illegality and reasons of refusal of cruise ships calls, numerous factors might also have contributed to this situation, such as geopolitics and international relations, which go beyond the scope of this study. Another limitation of the research is that the existing assessment of national core capacities took place before 2020. New assessment results need judging to figure out whether it is reasonable for some coastal countries to refuse cruise ships to call at their ports.

\section{DATA AVAILABILITY STATEMENT}

The raw data supporting the conclusions of this article will be made available by the authors, without undue reservation.

\section{AUTHOR CONTRIBUTIONS}

$\mathrm{ZH}$ and WL participated in conception of the research ideas, study design, and interpretation of the fundings. WL wrote the first draft of the manuscript. ZH made critical revisions on the manuscript and provided implications of the study fundings. Both authors gave final approval of the version to be published.

\section{FUNDING}

This research was funded by the National Social Science Fund: The Research on Legal Governance on Maritime Public Health (21CFX019). 


\section{REFERENCES}

Beijing Youth Daily (2020). A family of three visited Vietnam by Cruise and diagnosed covid-19 and infected relatives. Available online at: http://epaper. ynet.com/images/2020-02/07/A06/bjbqb20200207A06.pdf (accessed January 20, 2021)

Brewster, R. K., Sundermann, A., and Boles, C. (2020). Lessons learned for COVID19 in the cruise ship industry. Toxicol. Ind. Health 36, 728-735. doi: 10.1177/ 0748233720964631

Burci, G. L., and Quirin, J. (2018). Implementation of the International Health Regulations (2005): recent developments at the World Health Organization. Available online at: https://asil.org/insights/volume/22/issue/13/ implementation-international-health-regulations-2005-recent-developments (accessed January 20, 2021).

CDC (2018). Available VSP Outbreak Investigations. Atlanta: CDC

CDC (2020a). No sail order and other measures related to operations. Atlanta: CDC. CDC (2020b). No Sail Order and Suspension of Further Embarkation. Atlanta: CDC CDC (2021). Outbreak Updates for International Cruise Ships. Atlanta: CDC.

Choquet, A., and Sam-Lefebvre, A. (2020). Ports closed to cruise ships in the context of COVID-19: What choices are there for coastal States? Ann. Tourism Res. 86:103066. doi: 10.1016/j.annals.2020.103066

CLIA (2021). State of the cruise industry outlook. Available online at: https://cruising.org/-/media/research-updates/research/2021-state-of-thecruise-industry_optimized.ashx (accessed May 22, 2021).

Conventuslaw (2020). Malaysia - Impact Of COVID-19 Pandemic on Shipping. Available online at: https://www.conventuslaw.com/report/malaysia-impactof-covid-19-pandemic-on-shipping/ (accessed December 12, 2021)

Cruise Critic (2021). Coronavirus: which cruise ports are closed? Available online at: https://www.cruisecritic.com/news/5097/ (accessed May 22, 2021)

Cruise Industry News (2020). St. Lucia Turns Away AIDA Ship Due to Health Concerns. Available online at: https://www.cruiseindustrynews.com/cruisenews/22371-st-lucia-turns-away-aida-ship-due-to-health-concerns.html (accessed December 12, 2021)

EU Healthy Gateways (2020). Advice for health authorities and ship operators who have decided to suspend sailings and for the long-term docking of ships at the ports of EU/EEA MS during COVID-19 pandemic. Available online at: https: //www.healthygateways.eu/Portals/0/plcdocs/EU_HEALTHY_GATEWAYS_ COVID-19_Stationed_ships_18_3_2020_F.pdf?ver=2020-03-20-183254-500 (accessed May 20, 2021)

EU Healthy Gateways (2021). COVID-19: EU Healthy Gateways advice for cruise ships operations. Available online at: https://www.healthygateways.eu/ (accessed June 20, 2021)

Fidler, D., and WHO (2002). Global health governance: overview of the role of international law in protecting and promoting global public health. Available online at: https://apps.who.int/iris/handle/10665/68936 (accessed November 20, 2021)

Global Biodefense (2020). Secretary Azar Declares Public Health Emergency for United States for 2019 Novel Coronavirus. Available online at: https://globalbiodefense.com/2020/01/31/secretary-azar-declarespublic-health-emergency-for-united-states-for-2019-novel-coronavirus/ \#: : text=Health\%20and\%20Human\%20Services\%20Secretary,responding $\% 20$ to $\%$ 202019\%20novel\%20coronavirus.\&text=In\%20declaring\%20the\%20public\%20 health,the\%20Public\%20Health\%20Service\%20Act (accessed January 20, 2022)

Gong, X. Q. (2020). The dispute settlement mechanism of WHO International Health Regulations (2005). Wuhan Univers. Int. Law Rev. 4, 83-96.

Gostin, L. O. (2014). Global Health Law. London: Harvard University Press, 72.

Gostin, L. O., and Mok, E. A. (2009). Grand Challenges in Global Health Governance. Br. Med. Bull. 90:Id014. doi: 10.1093/bmb/ldp014

Gostin, L. O., DeBartolo, M. C., and Friedman, E. A. (2015). The International Health Regulations 10 Years On: The Governing Framework for Global Health Security. Lancet 386, 2222-2226. doi: 10.1016/S0140-6736(15)00948-4

Guardian (2020a). Cruise ship accounts for more than half of virus cases outside China - as it happened. Available online at: https://www.theguardian.com/ world/live/2020/feb/20/coronavirus-live-updates-diamond-princess-cruiseship-japan-deaths-latest-news-china-infections (accessed December 20, 2021)

Guardian (2020b). Twelve new Australian Covid-19 cases reported - as it happened. Available online at: https://www.theguardian.com/australia-news/live/2020/ apr/23/australia-coronavirus-live- updates-senate-inquiry-government- scott-morrison-nsw-victoria-queensland-ruby-princess-murphy-latest-news (accessed December 20, 2021)

Habibi, R., Burci, G. L., and de Campos, T. C. (2020). Do not violate the International Health Regulations during the COVID-19 outbreak. Lancet 395, 664-666. doi: 10.1016/S0140-6736(20)30373-1

Harris, S. (2020). More COVID-19 cases on stranded ship with 4 dead, as cruise line pleads for help. Available online at: https://www.cbc.ca/news/business/COVID19-zaandam-cruise-ship-ill-stranded-1.5515811 (accessed April 1, 2020)

Hoffman, S. J. (2014). Making the International Health Regulations Matter: Promoting Compliance Through Effective Dispute Resolution. Routledge Handbook on Global Health Security. London: Routledge, 239-240.

Icelandic Transport Authority (2020). Maritime Notice IMO-1-2020. Available online at: https://info.lr.org/l/12702/2020-05-29/93lhhb/ (accessed December $10,2020)$.

IMO (2021). COVID 19 - Guidance for Flag States Regarding Surveys and Renewals of Certificates During the COVID-19 Pandemic. Available online at: https://info. lr.org/l/12702/2020-06-05/948prz/ (accessed December 12, 2020).

Insider (2020). An Italian Cruise Ship was Turned Away From Ports in Malaysia and Thailand Even Though it has no Cases of Coronavirus on Board. Available online at: https://www.businessinsider.com/coronavirus-costa-fortuna-cruiseship-denied-by-malaysia-thailand-ports-2020-3 (accessed January 20, 2022)

Ito, H., Hanaoka, S., and Kawasaki, T. (2020). The cruise industry and the COVID19 outbreak. Transport. Res. Interdiscipl. Perspect. 5:100136. doi: 10.1016/j.trip. 2020.100136

Klein, N. (2020). International law perspectives on cruise ships and COVID-19. J. Int. Humanitarian Legal Stud. 11, 282-294. doi: 10.1163/18781527-bja10003

Lee, K., Worsnop, C. Z., Grépin, K. A., and Kamradt-Scott, A. (2020). Global coordination on cross-border travel and trade measures crucial to COVID-19 response. Lancet 395, 1593-1595. doi: 10.1016/S0140-6736(20)31032-1

Lewis, O., Walton, S., and Hayward, M. (2020). Coronavirus: Cruise ship passenger in Akaroa tests negative, company says. Available online at: https://www.stuff.co.nz/national/health/coronavirus/120289215/coronaviruscruise-ship-passenger-in-akaroa-canterbury-being-tested (accessed December 12, 2020)

Lin, C. F. (2020). COVID-19 and the Institutional Resilience of the IHR (2005): Time for a Dispute Settlement Redesign?. Available online at: https://petrieflom.law.harvard.edu/resources/article/COVID-19-and-theinstitutional-resilience-of-the-ihr-2005 (accessed June 20, 2021).

Liu, X. H. (2020). International law dimension of global governance of international public health security. Law Sci. 461, 19-32.

Liu, X., and Chang, Y. C. (2020). An emergency responding mechanism for cruise pandemic prevention-taking COVID-19 as an example. Mar. Policy. 119:104093. doi: 10.1016/j.marpol.2020.104093

Liu-Lastres, B., Schroeder, A., and Pennington-Gray, L. (2019). Cruise line customers' responses to risk and crisis communication messages: An application of the risk perception attitude framework. J. Travel Res. 58, 849-865.

Luxembourg Ministry of Economic (2020). Extraordinary measures related to crew documents and ship certificates in relation to the COVID-19 Pandemic. Available online at: https://info.lr.org/l/12702/2021-09-30/c373nx/12702/ 16329865031WWnCz9f/002_2020_nCoV_mesures_extraordinaires_updated_ 17112020.pdf (accessed December 10, 2021).

Morrison, A. P. (2012). Places of refuge for ships in distress: problems and methods of resolution. Leiden: Martinus Nijhoff Publishers, 10.

Negri, A., and Hardt, M. (2000). Empire. Cambridge: Harvard University Press, 136.

New Zealand Ministry of Health (2020). COVID-19 Update on Ruby Princess and Celebrity Solstice cruises. Available online at: https: //www.health.govt.nz/news-media/media-releases/covid-19-update-rubyprincess-and-celebrity-solstice-cruises (accessed December 10, 2021)

NIID (2020). Field Briefing: Diamond Princess COVID-19 Cases. Available online at: https://www.niid.go.jp/niid/en/2019-ncov-e/9407-covid-dp-fe-01. html (accessed December 20, 2021)

Ortolland, D., and Pirat, J. (2017). Geopolitical atlas of the oceans. Paris: Technip, 3. Puhak, J. (2020). Cruise ship MSC Meraviglia turned away from two Caribbean ports amid coronavirus concerns. Available online at: https://www.foxnews.com/ travel/cruise-ship-msc-meraviglia-coronavirus-concerns (accessed February 26, 2021) 
Sarkar, A., Liu, G. Q., Jin, Y. Z., et al. (2020). Public health preparedness and responses to the coronavirus disease 2019 (COVID-19) pandemic in South Asia: a situation and policy analysis. Glob. Health J. 4, 121-132. doi: 10.1016/j.glohj. 2020.11.003

Smorenberg, A., Peters, E. J., van Daele, P., Nossent, E. J., and Muller, M. (2021). How does SARS-CoV-2 targets the elderly patients? A review on potential mechanisms increasing disease severity. Eur. J. Intern. Med. 83, 1-5. doi: 10. 1016/j.ejim.2020.11.024

Stuff (2020). Dominican Republic turns back cruise ship amid virus fears. Available online at: https://www.stuff.co.nz/travel/news/119890954/dominican-republicturns-back-cruise-ship-amid-virus-fears (accessed December 12, 2021)

Sun, S. Q., and Jin, Y. W. (2020). Legal review on public health emergency management of international cruises. Dalian: Dalian Maritime University.

Tardivel, K., White, S. B., and Duong, K. K. (2016). Cruise Ship Travel. Available online at: https://wwwnc.cdc.gov/travel/yellowbook/2016/conveyancetransportation-issues/cruise-ship-travel (accessed December 12, 2021).

Tirrell, A., and Mendenhall, E. (2021). Cruise Ships, COVID-19, and Port/Flag State Obligations. Ocean Dev. Int. Law 2021:1913323. doi: 10.1080/00908320. 2021.1913323

Travel Agent Central (2020). Westerdam docks in Cambodia, guests cleared of coronavirus. Available online at: https://www.travelagentcentral.com/cruises/ westerdam-docks-cambodia-guests-cleared-coronavirus (accessed Febrary 14, 2021)

U.K. GOV (1999). White Paper: Modernising Government. Available online at: http://www.archive.official-documents.co.uk/document/cm43/4310/4310.htm (accessed January 20, 2022)

U.K. GOV (2020). The Health Protection (Coronavirus, Restrictions) (England) Regulations 2020. Available online at: http://www.legislation.gov.uk/uksi/2020/ 350/made (accessed November 19, 2020)

Wang, H. (2020). Annual report on CHINA's cruise industry (2020). Beijing: Social Science Literature Press, 23-24.

Wang, X. Q., Lin, Y., and Li, Z. P. (2010). Discussions on the prevention and control of infectious diseases on international cruise ships. Chin. J. Front. Health Quarant. 3, 159-161. doi: 10.1007/s11606-020-06067-8

WHO (2005). IHR and Ebola. Available online at: https://apps.who.int/iris/ bitstream/handle/10665/251743/EBSS3_INF4-en.pdf (accessed November 20, 2021).
WHO (2009). Assessment tool for core capacity requirements at designated airports, ports and ground crossings. Available online at: https://apps.who.int/iris/rest/ bitstreams/67123/retrieve (accessed June 20, 2021).

WHO (2010). "IHR core capacities at Points of Entry," in Report of a regional meeting Colombo, Sri Lanka. Available online at: https://apps.who.int/ iris/bitstream/handle/10665/205318/B4661.pdf? sequence $=1$ \&isAllowed $=y$ (accessed June 20, 2021).

WHO (2019). The temporary recommendations from the World Health Organization. Geneva: WHO.

WHO (2020). Coronavirus disease 2019 (COVID-19) Situation Report - 88. Geneva: WHO.

Yamahata, Y., and Shibata, A. (2020). Preparation for Quarantine on the Cruise Ship Diamond Princess in Japan due to COVID-19. JMIR Public Health Surveill. 6:18821. doi: $10.2196 / 18821$

Yoshifumi, T. (2015). The international law of the sea (2nd). London: Cambridge University Press, 260.

Yu, Y. Q., Zhang, B. M., Gu, J., and Zhao, L. (2017). Emergency response of a suspected malaria infected ship. Chin. J. Front. Health Quarant. 3, 227-228.

Zhang, Y.H. (2017). The development process, internal logic and construction path of evidence-based policy. Chin. Public Administrat. 11, 73-78.

Conflict of Interest: The authors declare that the research was conducted in the absence of any commercial or financial relationships that could be construed as a potential conflict of interest.

Publisher's Note: All claims expressed in this article are solely those of the authors and do not necessarily represent those of their affiliated organizations, or those of the publisher, the editors and the reviewers. Any product that may be evaluated in this article, or claim that may be made by its manufacturer, is not guaranteed or endorsed by the publisher.

Copyright (c) $2022 \mathrm{Hu}$ and $\mathrm{Li}$. This is an open-access article distributed under the terms of the Creative Commons Attribution License (CC BY). The use, distribution or reproduction in other forums is permitted, provided the original author(s) and the copyright owner(s) are credited and that the original publication in this journal is cited, in accordance with accepted academic practice. No use, distribution or reproduction is permitted which does not comply with these terms. 